\title{
BIODIESEL PRODUCTION FROM LINSEED OIL AND PERFORMANCE STUDY OF A DIESEL ENGINE WITH DIESEL BIO-DIESEL FUELS
}

\author{
Md. Nurun Nabi and S. M. Najmul Hoque* \\ Department of Mechanical Engineering, \\ Rajshahi University of Engineering and Technology. Rajshahi-6204, Bangladesh \\ *Email: najmul23@yahoo.com
}

\begin{abstract}
The use of biodiesel is rapidly expanding around the world, making it imperative to fully understand the impacts of biodiesel on the diesel engine combustion process and pollutant formation. Biodiesel is known as "the mono alkyl esters of long chain fatty acids derived from renewable lipid feedstock, such as vegetable oils or animal fats, for use in compression ignition (diesel) engines." Biodiesel was made by transesterification from linseed oil. In aspect of Bangladesh linseed can play an important role in the production of alternative diesel fuel. The climatic and soil condition of our country is convenient for the production of linseed (Linum Usitatissimum) crop. In the first phase of this work optimization of different parameters for biodiesel production were investigated. In the second phase the performance study of a diesel engine with diesel biodiesel blends were carried out. The results showed that with the variation of catalyst, methanol and reaction time; variation of biodiesel production was realized. About $88 \%$ biodiesel production was experienced with $20 \%$ methanol, $0.5 \%$ $\mathrm{NaOH}$ catalyst and at 550C. The results also showed that when compared with neat diesel fuel, biodiesel gives almost similar thermal efficiency, lower carbon monoxide (CO) and particulate matter (PM) while slightly higher nitrogen oxide (NOx) emission was experienced.
\end{abstract}

Keywords: Biodiesel, linseed oil, catalyst, alcohol and diesel emissions.

\section{INTRODUCTION}

Transesterification is the process of using an alcohol (e.g. methanol, ethanol or butanol), in presence of a catalyst, such as sodium hydroxide or potassium hydroxide, to break the molecule of the raw renewable oil chemically into methyl or ethyl esters of the renewable oil, with glycerol as a by product. Transesterification of triglycerides produces fatty acid alkyl esters and glycerol. The glycerol layer settles down at the bottom of the reaction vessel.

Researchers have investigated the important reaction conditions and parameters on the alcoholysis of triglycerides, such as fish oils, soybean, rapeseed, cottonseed, sunflower, safflower, peanut and linseed oils to produce ethyl and methyl esters (DuPlessis and DeVilliers ${ }^{1}$ ). They also prepared methyl and ethyl esters from palm and sunflower oils using $\mathrm{NaOH}$ as the catalyst and using $100 \%$ excess alcohol and applied heat in the reaction 1 . The stepwise reactions are reversible and a little excess of alcohol is used to shift the equilibrium towards the formation of esters. In presence of excess alcohol, the forward reaction is pseudo-first order and the reverse reaction is found of second order. It was also observed that transesterification is faster when catalyzed by an alkali ${ }^{2}$. Fatty acid esters have surprisingly good emissions characteristics. Mittelbach and Marr ${ }^{3}$ found that emissions of two different methyl ester fuels derived from rapeseed oil gave significantly lower total particulates and lower polynuclear aromatic hydrocarbons than diesel fuel ${ }^{3}$. However, combustion of methyl ester fuels produced higher levels of NOx emissions and aldehyde emissions than diesel fuel ${ }^{3}$. Nye and Southwell ${ }^{4}$ investigated the effects of several important reaction parameters on the methanolysis of rapeseed oil. They reported finding successful conditions at room temperature by systematically optimizing the other operating variables. They identified the main variables as catalyst type, catalyst concentration, oil/alcohol ratio and stirring rate. They found that one percent $\mathrm{NaOH}$ or $\mathrm{KOH}$ was an effective reaction rate enhancer at room temperature; a 60-minute reaction time was allowed. It was determined that a $6: 1$ molar ratio of methanol to oil gave the best conversion. They also found that the rate of reaction is satisfactory if the stirring action is vigorous with some slashing. Nye and Southwell ${ }^{4}$ extended their work on transesterification of rapeseed oil to produce the methyl ester in a bench-scale operation. They transesterified 25-litre (6.6 gallon) batches of oil in an enclosed stainless steel cylindrical drum which was equipped with a 4-inch diameter propeller driven by a $1 / 3$ horsepower electric motor. Rapeseed oil was added to a solution of $1 \%$ sodium hydroxide (by weight relative to oil) dissolved in 6 molar equivalents of dry methanol. The solution was stirred with splashing for one hour at $24^{\circ} \mathrm{C}$. The mixture was allowed to separate into two phases: one phase is rich in glycerin and unreacted methanol, the other phase is rich in glycerin and unreacted methanol. The ester phase was washed three times with water equal to half the volume of ester to remove methanol and potassium compounds. The ester was then dried over anhydrous calcium chloride and filtered ${ }^{4}$.

\begin{tabular}{ll}
\hline $\begin{array}{l}\text { Nomenclature } \\
\text { API }\end{array}$ & American Petroleum Institute \\
BMEP & Brake Mean Effective Pressure \\
BSFC & Brake Specific Fuel consumption \\
$\mathrm{B} 10$ & $10 \%$ Biodiesel \\
$\mathrm{B} 20$ & $20 \%$ Biodiesel \\
$\mathrm{B} 50$ & $50 \%$ Biodiesel \\
$\mathrm{B} 100$ & $100 \%$ Biodiesel \\
$\mathrm{CO}_{2}$ & Carbon Dioxide \\
$\mathrm{CO}$ & Carbon Monoxide \\
$\mathrm{KOH}$ & Potassium Hydroxide \\
$\mathrm{LOME}$ & Linseed Oil Methyl Ester \\
$\mathrm{MEWR}$ & Methyl Ester of Winter Rape \\
$\mathrm{NA}$ & Naturally Aspirated \\
$\mathrm{NaOH}$ & Sodium Hydroxide \\
$\mathrm{NOx}$ & Nitrogen Oxide \\
$\mathrm{PM}$ & Particulate Matter \\
rpm & Revolution per minute \\
\hline
\end{tabular}


Similar results have been reported by Mills and Howard ${ }^{5}$. Additional long term engine tests, cold starting tests, and studied of gaseous emissions are needed before vegetable oil fuels can be commercialized. Both engine modification and fuel medication have potential for enhancing engine heat release rates and further reducing exhaust emissions ${ }^{5}$. Peterson et $a l^{6}$ have given a complete description of the process for the production of the methyl ester of winter rape [MEWR]. MEWR has been manufactured in a 756-litrer [200-U.S. gallons] batch pilot plant scale using potassium hydroxide as a catalyst. The MEWR bio-diesel product has been used as a replacement for diesel fuel in laboratory studies and in tractions using the ester under actual field conditions. A $20 \mathrm{KW}$ (27 hp) Satoh tractor has been powered with 100\% MEWR biodiesel since the spring of 1987. The tractor has been performing satisfactorily to date. A preliminary economic analysis of the commercial production of MEWR showed a break-even cost of $\$ 0.49 /$ litre [ $\$ 1.85 /$ U.S. gallon]. Costs are in 1991 U.S. dollar. Clark et al trans-esterified soybean oils into ethyl and methyl esters, and compared the performances of the fuels with diesel. Stem et $a l^{8}$ worked on a process with at least two esterification. The first esterification was catalyzed by an acidic chemical and the second by an alkali. Almost all the investigators indicated that for a successful transesterification, preheating and/or heating the mixture of oil, alcohol, and catalyst during the reaction was necessary to get satisfactory results. The application of heat during the reaction is not economically sound because of the additional cost and reduced energy efficiency ${ }^{8}$.

\section{TEST PROCEDURE}

The engine used in this experiment was a single cylinder water-cooled, naturally aspirated (NA) 4-stroke DI diesel engine. The specifications of the engine are shown in Table 1.

The experiment was conducted with conventional diesel fuel, Linseed oil methyl ester (LOME). The rpm was measured directly from the tachometer attached with the dynamometer. The outlet temperatures of cooling water and exhaust were measured directly from the thermometer attached to the engine. The exhaust gases including NOx, $\mathrm{CO}$, were measured with a portable digital gas analyzer (IMR 1400). The data of exhaust emissions were taken from the end of the exhaust pipe of the engine. The engine speed was kept fixed at $1000 \mathrm{rpm}$. The exhaust gas temperature was measured by the gas analyzer from the exhaust pipe. An inclined water tube manometer, connected to the air box (drum) was used to measure the

Table 1. Test Engine Specifications.

\begin{tabular}{|l|l|}
\hline Engine type & 4-stroke DI diesel engine \\
\hline Number of cylinders & One \\
\hline Bore $\times$ Stroke & $80 \times 110 \mathrm{~mm}$ \\
\hline Swept volume & $553 \mathrm{cc}$ \\
\hline Compression ratio & $16.5: 1$ \\
\hline Length of exhaust pipe & 36 inch \\
\hline Rated power & $4.476 \mathrm{Kw@1800} \mathrm{rpm}$ \\
\hline Engine No & $4062 \mathrm{AVI}$ \\
\hline & $\begin{array}{l}14 \mathrm{MPa}(\text { at low speed, } 900 \text { to } \\
1000 \mathrm{rpm}) \\
20 \mathrm{MPa}(\text { at high speed, } 1100 \\
\text { Fuel injection pressure } 2000 \mathrm{rpm})\end{array}$ \\
\hline
\end{tabular}

air pressure. Fuel consumption was measured by a burret attached to the engine fuel. A stopwatch was used to measure fuel consumption time for every $10 \mathrm{cc}$ fuel. The engine was electrically loaded.

At first 20 percent methanol (99.9\% pure) and 0.5 percent sodium hydroxide to a strong glass bottle with a narrow neck to prevent splashing. Then it is shacked well. It takes 15 minutes to mix and in the mean time it become hot fumed. The product of the mixture is sodium methoxide. Meanwhile 1 (one) litter of new linseed oil is taken into a glass bottle and heated in electric oven to about $40^{\circ} \mathrm{C}$ to $55^{\circ} \mathrm{C}$ to thin it. Then the sodium hydroxide and hot oil is mixed and stirred well for about 1 hour and placed a new mixture on the oven about $55^{\circ} \mathrm{C}$ (the bottle was made of Pyrex so it is able to withstand up $350^{\circ} \mathrm{C}$ ) for 24 hours. After 24 hours we found a clear reddish liquid on the top with heavy black glycerin setting out of the bottom. Now biodiesel is separated manually from glycerin so that biodiesel doesn't contain any part of glycerin.

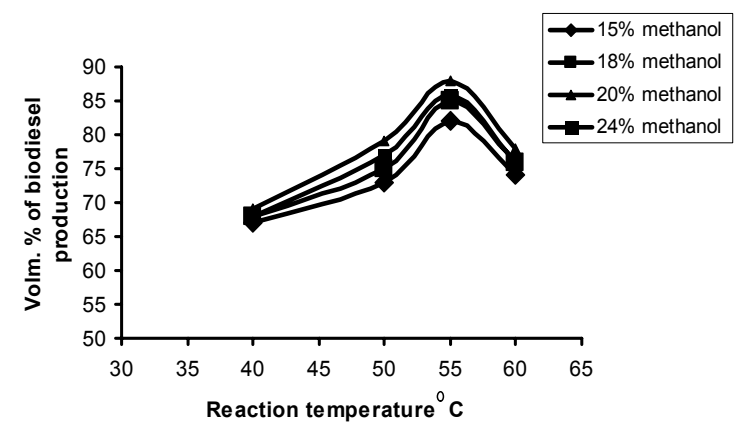

Figure 1: Effect of Methanol percentages on Biodiesel production $(\mathrm{NaOH}=0.5 \%)$

\section{RESULTS AND DISCUSSION}

Effect of Methanol Percentages on Biodiesel Production Figure 1 illustrates the effect of methanol on biodiesel production. The percentage of Catalyst $(\mathrm{NaOH})$ was kept constant at $0.5 \%$ and reaction temperature was varied. It was clear that with the increase in percentage of methanol the tendency of biodiesel production was also increased. This was because the presence of excess methanol $\left(\mathrm{CH}_{3} \mathrm{OH}\right)$ in the reaction greatly influences the conversion of ester from vegetable oil. The bio-diesel was found $88 \%$ at $0.5 \% \mathrm{NaOH}, 20 \%$ methanol and temperature $55^{\circ} \mathrm{C}$. But at $24 \%$ methanol biodiesel production decreased in order to create large amount of glycerol, soap and wax.



Figure 2: Effect of catalyst $(\mathrm{NaOH})$ percentages on Biodiesel production $\left(\mathrm{CH}_{3} \mathrm{OH}=20 \%\right)$ 
Effect of Catalyst Percentages on Biodiesel Production

Figure 2 shows the effect of catalyst percentages on biodiesel production. The percentages of $\mathrm{NaOH}$ were varied from $0.4 \%$ to $0.7 \%$ and optimum methanol percentages fixed to $20 \%$. The temperature was also varied from $\left(40^{0} \mathrm{C}-60^{\circ} \mathrm{C}\right)$. From the graph, it was observed that biodiesel production was decreased after increasing the catalyst. The linseed oil contains higher free fatty acid which reacts with catalyst and forms more wax and glycerol by transesterification. The maximum $89 \%$ biodiesel production was found at $0.5 \% \mathrm{NaOH}$ and at a reaction temperature of $55^{\circ} \mathrm{C}$. Here $20 \%$ methanol and $0.5 \% \mathrm{NaOH}$ were chosen as the maximum percentages of biodiesel production.

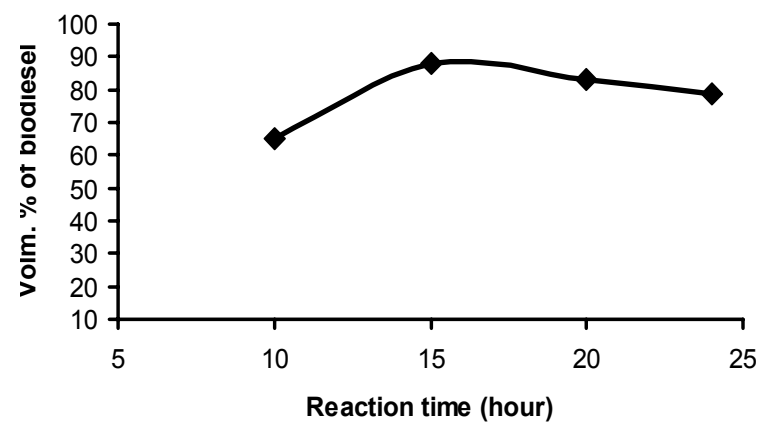

Figure 3: Effect of reaction time on Biodiesel production $\left(\mathrm{CH}_{3} \mathrm{OH}=20 \%, \mathrm{NaOH}=0.5 \%\right)$

\section{Effect of Reaction Time on Biodiesel Production}

Figure 3 depicts the effect of reaction time on biodiesel production. Volumetric percentage of methanol was kept at $20 \%$, while the catalyst weight percentage was kept at $0.5 \%$ and the reaction temperature was kept at $55^{\circ} \mathrm{C}$. It was found that when reaction time increases, and biodiesel production increases and reaches maximum at 15 hours. Then biodiesel production decreases with increase in reaction time. This may be associated with the increase in wax formation with the increase in reaction time. Also noticed that when the mixture was kept for long time, alcohol got enough time to evaporate, decreases the conversion of esters. So maximum biodiesel production was $88 \%$ at 15 hours.

\section{Comparison of Different Parameters among Diesel, Biodiesel and Pitraj Oil}

Table 2 illustrates the comparison of different parameters among diesel, biodiesel and pitraj oil. The cetane index of biodiesel from pitraj oil is higher than the diesel which indicates the well combustion of biodiesel than diesel. The density, viscosity and higher heating value were found close to diesel which also indicates the importance of this fuel. Only disadvantageous properties

Table 2. Properties of test Diesel and Bio-diesel.

\begin{tabular}{lccc}
\hline \multicolumn{1}{c}{ Properties } & $\begin{array}{c}\text { Neat } \\
\text { Diesel }\end{array}$ & $\begin{array}{c}\text { Bio- } \\
\text { Diesel }\end{array}$ & $\begin{array}{c}\text { Linseed } \\
\text { Oil }\end{array}$ \\
\hline Viscosity (cp) at $20^{\circ} \mathrm{C}$ & 5.7 & 8.2 & 10 \\
Density (gm/cc) & 0.852 & 0.872 & 0.921 \\
Higher Cal. Val. $(\mathrm{KJ} / \mathrm{kg})$ & 43500 & 37500 & 35225 \\
Sp. gravity & 0.852 & 0.872 & 0.921 \\
API gravity & 34.52 & 30.77 & 23 \\
Aniline point $\left({ }^{\circ} \mathrm{F}\right)$ & 75 & 86 & 92
\end{tabular}



Figure 4: Thermal efficiency for neat Diesel fuel and Diesel-Biodiesel blends (Engine Load $=44 \mathrm{~N}$ ).

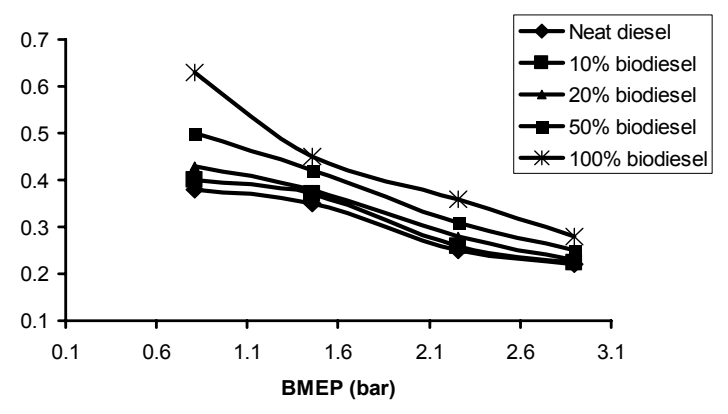

Figure 5: Brake specification fuel consumption with engine BMEP for neat Diesel and Diesel-Biodiesel blends $($ Engine speed $=1000 \mathrm{rpm})$.

were found that is flash point, which is higher than the diesel, but similar with other biodiesel.

\section{Thermal Efficiency for Neat Diesel Fuel and Diesel- Biodiesel Blends}

Figure 4 shows the brake thermal efficiency of the engine increases with increase of engine speed (rpm) at constant load $(44 \mathrm{~N})$. After reaching the maximum value of efficiency then goes to decrease. This is due to the fact that, initially with the increases of engine rpm the torque produced by the engine increase, hence the efficiency also increases. But at higher rpm $(>1000)$ more amount of fuel is injected into the engine cylinder per cycle and due to higher engine speed this fuel does not get sufficient time to burn completely which reduce the efficiency of the engine. Figure also shows that efficiency of the engine at B10 and B20 is almost similar to neat diesel but B50 and B100 is slightly lower than diesel because of higher viscosity and higher flash point of bio-diesel.

Brake Specification Fuel Consumption with Engine BMEP for Neat Diesel and Diesel-Biodiesel Blends (Engine Speed $=1000 \mathrm{rpm}$ )

Brake specific fuel consumption (BSFC) decreases with the increase in brake mean effective pressure which is shown in Figure 5. Because of increasing brake mean effective pressure (BMEP), the time for an amount of fuel consumption decreases but with the increase in brake means effective pressure the brake power of the engine increases. As a result the brake specific fuel consumption decreases. The BSFC for same amount of power production, for biodiesel $(\mathrm{B} 10, \mathrm{~B} 20)$ is almost similar to conventional diesel fuel. 


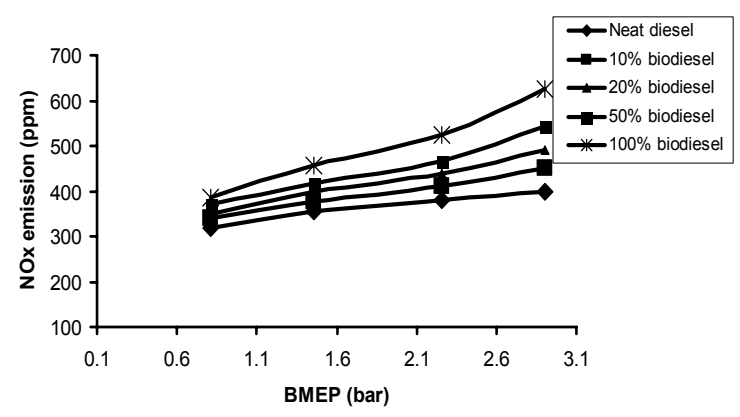

Figure 6: Variation of NOx emission with engine BMEP for neat Diesel fuel and Diesel-Biodiesel blends (Engine Speed $=1000 \mathrm{rpm}$ ).

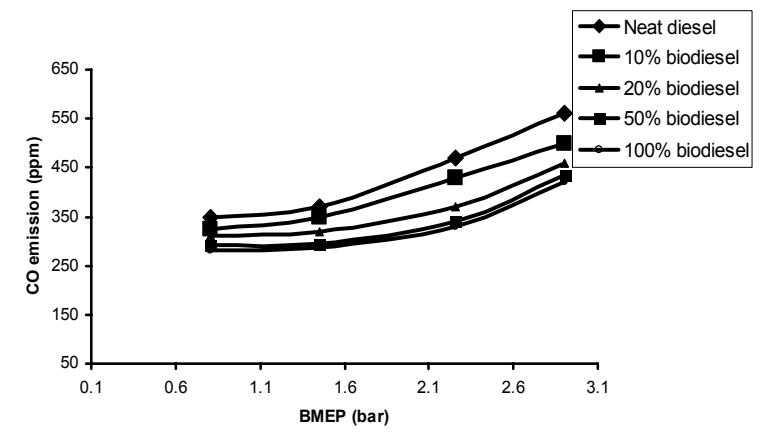

Figure 7: Variation of CO emission with engine BMEP for neat Diesel fuel and Diesel-Biodiesel blends (Engine Speed $=1000 \mathrm{rpm})$.

Variation of NOx Emission with Engine BMEP for Neat Diesel Fuel and Diesel-Biodiesel Blends (Engine Speed $=1000 \mathrm{rpm}$ )

Figure 6 shows that the change of exhaust gas NOx of linseed oil (LO) with in BMEP (bar). From the figure it is seen that with increases in BMEP and load then the amount of NOx emission increases. When load increases- that means BMEP increases, temperature increases inside the combustion chamber and sufficient $\mathrm{O}_{2}$ (oxygen) present in linseed oil gives much amount of NOx concentration in the exhaust. With increases in BMEP fuel consumption and power output increases. At the end of combustion, combustion gas temperature arises about $25000 \mathrm{C}$. At this temperature level oxidation of nitrogens take places in presence of oxygen inside the cylinder. On the other hand, the formation of NO does not attain chemical equilibrium reaction, then after the end of expansion stroke when the burn gases cool and the formation of NOx freeze, the concentration of formed NOx in the exhaust gas remain unchanged. This figure also shows that NOx level is higher for diesel-biodiesel blends B10, B20 than conventional diesel fuel at same BMEP.

Variation of CO Emission with Engine BMEP for Neat Diesel Fuel and Diesel-Biodiesel Blends (Engine Speed = $1000 \mathrm{rpm}$

From the Figure 7, it was shown that with increases in BMEP and load then the amount of $\mathrm{CO}$ emission increases. Carbon monoxide (CO) occurs only in engine exhaust, it is a product of incomplete combustion due to insufficient amount of air or insufficient time in the cycle complete combustion. Carbon monoxide (CO) increases because of fuel consumption increases with increase in BMEP. In diesel engine combustion takes places normally at higher
$\mathrm{A} / \mathrm{F}$ ratio, therefore sufficient oxygen is available to burn all the carbon in the fuel fully to $\mathrm{CO}_{2}$. The oxidation reaction is not irreversible reaction like oxidation of nitrogen the process is limited (below certain temperature level, $>1500 \mathrm{~K})$ by the phenomenon of dissociation. During this dissociation $\mathrm{CO}_{2}$ split into $\mathrm{CO}$ and $\mathrm{O}_{2}$. If sufficient energy is supplied to $\mathrm{CO}_{2}$, collision takes place between some of the $\mathrm{CO}_{2}$ molecules. For biodiesel $\mathrm{CO}$ emission level is lower than that of diesel, in order to gives $10 \%$ to $20 \%$ extra oxygen. Due to the presence of extra oxygen, additional oxidation reaction takes place between $\mathrm{O}_{2}$ and $\mathrm{CO}$. This oxidation reaction gives lower $\mathrm{CO}$ emission in $\mathrm{B} 10, \mathrm{~B} 20, \mathrm{~B} 50$ and $\mathrm{B} 100$ than conventional diesel by producing excess $\mathrm{CO}_{2}$ in complete combustion.

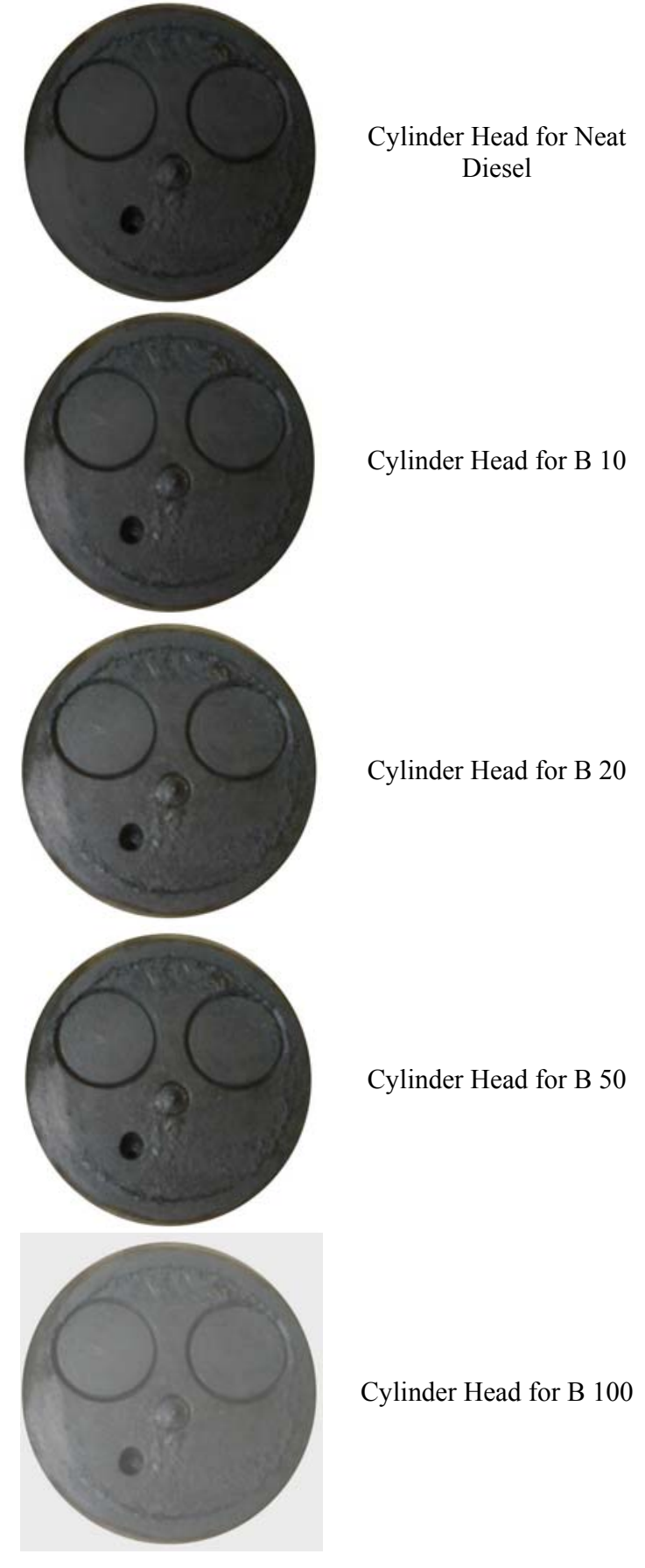

Figure 8: Cylinder head for Diesel engine by using neat Diesel, B10, B20, B50 and B100. 
Effect of Biodiesel Combustion on Carbon Deposit to the Cylinder Head

Figure 8 shows the effect of biodiesel combustion on carbon deposit to the cylinder head. The engine was run with neat diesel fuel, biodiesel and diesel-biodiesel blends respectively. Photographs of cylinder head were taken by using B10, B20, B50, and B100 blends. These Photographs are shown correspondingly. From photographs, it is seen that the cylinder head of diesel looks blacker than that of $\mathrm{B} 10, \mathrm{~B} 20, \mathrm{~B} 50$, and B100 and the photograph of cylinder head for B100 is brighter than that for other blends. The reason of these for the particulate emission from CI engine with diesel is higher than that of biodiesel because biodiesel contains $10-15 \%$ extra oxygen, which results better combustion of fuel and lower particulate emission.

\section{CONCLUSIONS}

The production of biodiesel from Linseed oil and performance study of a diesel engine with diesel biodiesel fuels was carried out. The result may be summarized as follows:

1. Production of biodiesel from linseed oil by transesterification process.

2. The properties of Linseed oil, biodiesel are comparable with conventional diesel fuels.

3. Maximum $88 \%$ biodiesel production was found at $20 \%$ methanol, $0.5 \% \mathrm{NaOH}$ and $55^{\circ} \mathrm{C}$ reaction temperature.

4. The maximum biodiesel production measured after 15 hrs. Reaction time.

5. Thermal efficiency of biodiesel is almost similar to conventional diesel fuel. Efficiency of biodiesel (B10, B20) is $1 \%$ and $2 \%$ lower than diesel fuel due to low volatility, higher viscosity and density.

$\mathrm{CO}$ emissions reduced with diesel biodiesel blended fuel, while NOx emission increased for the diesel biodiesel blended fuel compared with the conventional diesel fuel. Biodiesel (B10, B20) reduces $9 \%$ and $23 \% \mathrm{CO}$ emission than diesel fuel. But NOx level is $6 \%$ and $13 \%$ higher than diesel fuel.

\section{REFERENCES}

[1] Du Plessis, L. M., De Villiers, J. B. M. and Van Der Walt, W. H., 1985, "Stability Studies on Methyl and Ethyl Fatty Acid Esters of Sunflowerseed Oil," Journal of the American Oil Chemists' Society, Vol. 62(4), pp. 748-752.
[2] Freedman, B., Butterfield, R. O. and Pryde, E. H., 1986, "Transesterification kinetics of soybean oil". Journal of the American Oil Chemists' Society Vol. 63(10), pp. 1375-1390.

[3] Mittelbach, M. and Marr, R., 1995, "A low waste process for the production of biodiesel", Sep Science Technology, Vol. 30 (7-9), pp. 2021-2033.

[4] Nye, M. J. and Southwell, P. H., 1983, "Esters from Rapeseed Oil as Diesel Fuel," from Vegetable Oils as Diesel Fuel, Seminar III, Agricultural Reviews and Manuals, ARM-NC-28, Document No. A 77.30: NC28, October 19-20, Peoria, Ill.

[5] Mills, G. A. and Howard, G. A. "A Preliminary Investigation of Polynuclear Aromatic Hydrocarbon Emissions from a Diesel Engine Operating on Vegetable Oil-Based Alternative Fuels".

[6] Peterson, C. L., Feldman, M., Korus, R. and Auld, D. L., 1991, "Batch Type Transesterification Process for Winter Rape Oil," Transactions of the ASAE Applied Engineering in Agriculture, Vol. 7(6), pp. 711-716.

[7] Clark, S. J., Wagner, L., Schrock, M. D. and Piennaar, P. G., 1984, "Methyl and Ethyl Soybean Esters as Renewable Fuels for Diesel Engines," Journal of the American Oil Chemists' Society, Vol. 61(10), pp. 1632-1638.

[8] Stern, R., Hillion, G., Gateau, P. and Guibet, J. C., 1987, "Process for Manufacturing a Composition of Fatty Acid Esters Useful as Gas Oil Substitute Motor fuel with Hydrated Ethyl Alcohol and he Resultant Esters Composition," U.S. Patent 4,695, 411. Awarded Sept. 22. 